\title{
The Walgidee Hills zoned lamproite intrusion, West Kimberley Province, Western Australia
}

\author{
A.L. Jaques \\ Research School of Earth Sciences, Australian National University, Canberra, ACT, Australia \\ Emaillynton.jaques@anu.edu.au
}

\section{Introduction}

Walgidee Hills is the largest ( 2.5 km in diameter) and, at $17.5 \mathrm{Ma}$, the youngest lamproite in the Miocene West Kimberley lamproite province which lies at the southwest margin of the Kimberley Craton of Western Australia (Jaques et al. 1986). The Walgidee Hills intrusion is the type location for several $\mathrm{K}$-, $\mathrm{Ba}-$ and Ti-rich minerals characteristic of lamproite, including priderite $\left.(\mathrm{K}, \mathrm{Ba})\left(\mathrm{Ti}, \mathrm{Fe}^{3+}\right)_{8} \mathrm{O}_{16}\right)$, wadeite $\left(\mathrm{K}_{2} \mathrm{ZrSi}_{3} \mathrm{O}_{9}\right)$, jeppeite $\left.(\mathrm{K}, \mathrm{Ba})_{2}(\mathrm{Ti}, \mathrm{Fe})_{6} \mathrm{O}_{13}\right)$, and noonkanbahite $\left(\mathrm{BaKNaTi}_{2} \mathrm{Si}_{4} \mathrm{O}_{14}\right.$ : Wade and Prider 1939; Jaques 2016). Previous reconnaissance studies have shown that Walgidee Hills is concentrically zoned in terms of grain size, mineralogy, and mineral and rock composition, ranging from olivine-, $\mathrm{MgO}-$, and Ni-rich lamproite through to coarse grained lamproite with low $\mathrm{MgO}$ and $\mathrm{Ni}$ contents at the centre of the intrusion (Jaques et al. 1986). This abstract summarises results of a detailed integrated study of the petrology and geochemistry of Walgidee Hills.

\section{Geology and Petrography}

Geological mapping and company exploration drilling at the margins of the Walgidee Hills intrusion has shown that a thin $(\leq 25 \mathrm{~m})$ layer of porphyritic olivine lamproite and tuff with abundant country rock fragments occurs at the outer margin of and beneath the main magmatic lamproite forming the intrusion. The Walgidee Hills intrusion is zoned from porphyritic olivine (altered) lamproite at the margin of the intrusion through medium grained lamproite comprised of olivine (altered), diopside, Tiphlogopite, leucite (altered but with very rare surviving grains) and Ti-potassic richterite with accessory priderite, perovskite, apatite, and wadeite to coarse gained and pegmatitic lamproite rich in K-Ti richterite, priderite, jeppeite, perovskite, apatite, wadeite and noonkanbahite at the centre of the body (Jaques et al. 1986). The pronounced coarsening in grain size of the Walgidee Hills lamproite is illustrated by perovskite which increases from $<50 \mu \mathrm{m}$ in the porphyritic olivine lamproite up to $\sim 2.5$ $\mathrm{cm}$ in the pegmatitic lamproite. Similarly, priderite increases in size across the body from $<100 \mu \mathrm{m}$ near the margins to $4 \mathrm{~cm}$ in the pegmatitic lamproite at the centre. Lithological zoning from the margins to the centre of the intrusion and textural relationships within samples suggests that the paragenetic sequence is: olivine - chromian spinel - diopside - perovskite - leucite - phlogopite - apatite - priderite - wadeite - titanian potassium richterite - sanidine - jeppeite - noonkanbahite.

\section{Mineral zoning}

Modest compositional zoning is evident from outer to inner zone rocks and from cores to rims of individual grains of $\mathrm{Cr}$ spinel, phlogopite (to lower $\mathrm{Mg}, \mathrm{Al}$ and higher $\mathrm{Fe}$ ) and, to a lesser extent, in $\mathrm{Ti}$ $\mathrm{K}$-richterite (to higher $\mathrm{Fe}, \mathrm{Na}$ ), priderite (to lower $\mathrm{Cr}$ ) and perovskite. However, zoning of individual grains is mostly confined to the fine-grained porphyritic olivine lamproite at the margins of the intrusion, and most individual grains in coarser grained rocks show only limited zoning, consistent with slow cooling of most of the Walgidee Hills intrusion. Spinels are almost entirely restricted to the porphyritic olivine lamproite and range in composition from titanian magnesiochromite with 3-8 wt \% $\mathrm{TiO}_{2},<5$ wt $\% \mathrm{Al}_{2} \mathrm{O}_{3}$, and 5-11 wt $\% \mathrm{MgO}$ to titanian chromites with lower $\mathrm{MgO}(<5 \mathrm{wt} \%)$ and higher $\mathrm{Fe}$ and $\mathrm{Cr}_{2} \mathrm{O}_{3}$ contents. These spinels are considerably more evolved than those found in the olivine lamproites of the Ellendale Field (Stachel and Brey 1993; Jaques 2016). Phlogopite is characterised by high $\mathrm{TiO}_{2}$ (up to $10 \mathrm{wt} \%$ ) and modest $\mathrm{Al}_{2} \mathrm{O}_{3}$ (up to $9 \mathrm{wt} \%$ ). It follows a trend to lower $\mathrm{Al}$ contents with decreasing $\mathrm{Mg} /(\mathrm{Mg}+\mathrm{Fe})$ (increasing $\mathrm{FeO}$ ), typical of lamproites (Mitchell and Bergman 1991) and similar to the coarser groundmass phlogopite in the Ellendale olivine lamproites and more Mg-rich phlogopite in the diopside-K-richterite-phlogopite-leucite lamproites (Jaques et al. 
1986; Stachel et al. 1994). The K-richterite has high $\mathrm{TiO}_{2}(3-7 \mathrm{wt} \%)$ and low $\mathrm{Na}_{2} \mathrm{O}$ (2-7 wt \%) contents and shows an increase $\mathrm{Ti}$ (and lesser increase in $\mathrm{Na}$ and $\mathrm{Na} /(\mathrm{Na}+\mathrm{K})$ ) and a decrease in $\mathrm{Al}$ with decreasing $\mathrm{Mg} /(\mathrm{Mg}+\mathrm{Fe})$. Walgidee Hills perovskites contain significant $\mathrm{Sr}, \mathrm{Nb}$ and LREE, and have highly fractionated REE patterns strongly enriched in LREE (Jaques 2016). The perovskites define an evolutionary trend of enrichment in $\mathrm{Na}, \mathrm{Sr}, \mathrm{Y}, \mathrm{Nb}, \mathrm{U}$ and $\mathrm{REE}$, and depletion in $\mathrm{Cr}, \mathrm{Fe}$, and Th towards the centre of the body. Early crystallised perovskite has significant $\mathrm{Cr}_{2} \mathrm{O}_{3}$ contents (up to $1.2 \mathrm{wt} \%$ ) and $\operatorname{LREE}\left(\mathrm{La} / \mathrm{Yb}_{\mathrm{N}}=1100-2500\right)$ whereas late crystallising perovskite at the centre of the intrusion has higher U, Y, and HREE but shows a decrease in LREE relative to HREE in earlier crystallised perovskite LREE $\left(\mathrm{La} / \mathrm{Yb}_{\mathrm{N}}<1000\right.$, decreasing to $\left.<500\right)$ due to extended crystallisation of LREEenriched perovskite and apatite (Jaques 2016).

\section{Geochemical zoning}

Whole rock analyses show a decrease in $\mathrm{MgO}, \mathrm{Ni}$ and $\mathrm{Cr}$, and increase in $\mathrm{Fe}, \mathrm{Ti}, \mathrm{Y}, \mathrm{Zr}, \mathrm{Nb}, \mathrm{Hf}, \mathrm{Rb}$, REE, and Th abundances inwards towards the most evolved rocks at the centre of the intrusion (Fig. 1). The zoning is well displayed by the $\mathrm{MgO}$ and $\mathrm{Ni}$ contours over the eastern part of the intrusion based on sampling of grid drilling (Jaques et al. 1986). The porphyritic olivine lamroite at the outer margin is characterised by moderate to high $\mathrm{MgO}$ and $\mathrm{Ni}$ contents $(14-18 \% \mathrm{MgO}, 500-600 \mathrm{ppm} \mathrm{Ni}$ ) and passes inwards through more $\mathrm{MgO}-$ and Ni-rich $(18-22 \mathrm{wt} \% \mathrm{MgO}, 600-700 \mathrm{ppm} \mathrm{Ni})$ medium grained lamproite into the $\mathrm{MgO}$ - and Ni-poor pegmatitic lamproites $(\sim 4-10 \mathrm{wt} \% \mathrm{MgO},<200 \mathrm{ppm} \mathrm{Ni},<100$ ppm $\mathrm{Cr}$ ) at the centre.

Samples on a north-south transect shows the increase in $\mathrm{TiO}_{2}, \mathrm{Y}, \mathrm{Zr}$ and $\mathrm{Nb}$ towards the centre of the intrusion, and the decrease in $\mathrm{MgO}, \mathrm{Ni}$ and $\mathrm{Cr}$ (Fig. 1). Increases towards the centre of the body are evident in $\mathrm{Fe}$ (total), $\mathrm{P}_{2} \mathrm{O}_{5}, \mathrm{Sr}$, and $\mathrm{Ba}$ contents and also, to a lesser extent, $\mathrm{K}_{2} \mathrm{O}, \mathrm{Rb}, \mathrm{Pb}$, Th and $\mathrm{U}$. A greater dispersion of some of the LIL elements (e.g. K, Rb, Ba, $\mathrm{U}$ ) is thought to be due to the effects of low temperature alteration. The Walgidee Hills lamproites exhibit a strong near-linear correlation of $\mathrm{Ni}$ and $\mathrm{Cr}$ and an inverse correlation of $\mathrm{TiO}_{2}, \mathrm{~K}_{2} \mathrm{O}$, and most LIL elements (e.g. Rb, Sr, LREE, Th) and high field strength cations (e.g. Y, $\mathrm{Zr}, \mathrm{Nb}, \mathrm{Hf}$ ) with $\mathrm{MgO}$, similar to that observed in the West Kimberley lamproites generally (Jaques et al. 1984, 1986). The Walgidee Hills lamproites have parallel highly fractionated REE patterns strongly enriched in LREE ( $\mathrm{La}_{\mathrm{CN}} \sim 520-1450 \mathrm{x}, \mathrm{Lu} \sim 3.8-10 \mathrm{x}$ ) with the lowest REE abundances found in the most MgO-rich lamproites and the highest REE abundances in the pegmatitic lamproites.
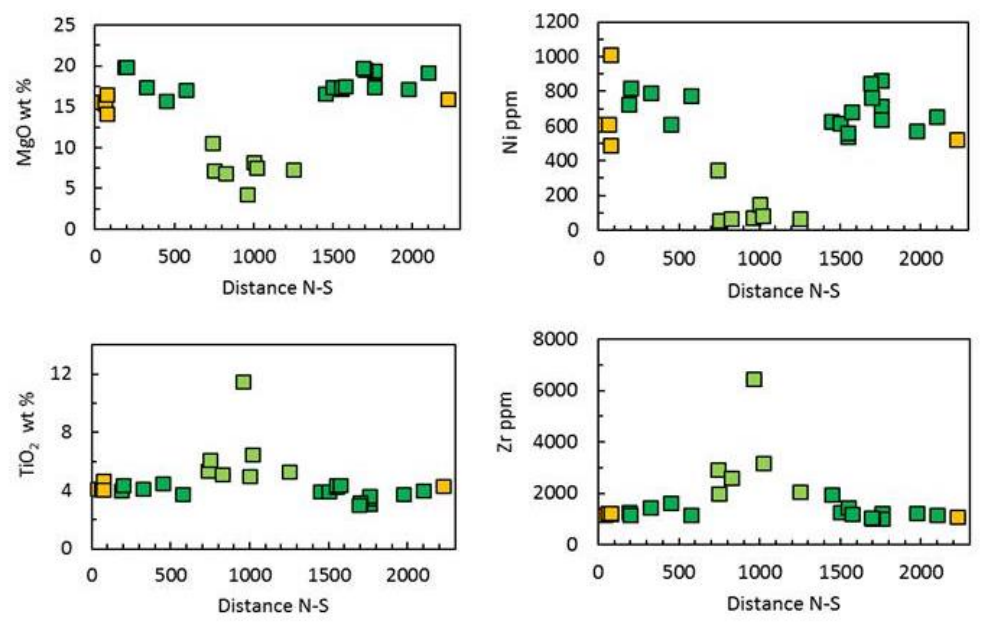

$\square$ Porphyritic olivine lamproite $\square$ Medium grained lamproite $\square$ Pegmatitic lamproite

Figure 1. Geochemical variation in rock geochemistry shown by selected major and trace elements within the Walgidee Hills intrusion. 
There is a strong correlation of major and trace elements with $\mathrm{MgO}$ which, coupled with the presence of macrocrystic olivine, suggests that the geochemical variation is controlled in part by accumulation and fractionation of olivine. The porphyritic olivine lamproite at the margin of the intrusion has a relatively uniform composition $\left(\mathrm{SiO}_{2} 43.1 \pm 0.8, \mathrm{TiO}_{2} 4.2 \pm 0.1, \mathrm{Al}_{2} \mathrm{O}_{3} 5.7 \pm 0.3 \mathrm{Fe}\right.$ as $\mathrm{Fe}_{2} \mathrm{O}_{3} 7.5 \pm 0.2, \mathrm{MnO}$ $0.10, \mathrm{MgO} 15.7 \pm 1.0, \mathrm{CaO} 4.1 \pm 0.4, \mathrm{Na}_{2} \mathrm{O} 0.40 \pm 0.1, \mathrm{~K}_{2} \mathrm{O} 6.3 \pm 1.3, \mathrm{P}_{2} \mathrm{O}_{5} 1.0 \pm 0.5$ wt \%, Cr $770 \pm 80$, Ni $550 \pm 50 \mathrm{ppm}$ ) and might approximate the parent magma composition for the Walgidee Hills intrusion. Preliminary modelling suggests that the more $\mathrm{MgO}$-rich lamproites $(\sim 20 \% \mathrm{MgO})$ can be approximated by incorporation of $\sim 10-12 \mathrm{wt} \%$ of mantle olivine whereas the more evolved coarse grained lamproites at the centre of the body are the result of slow cooling and extended fractional crystallisation.

\section{Conclusions}

Walgidee Hills is unusual in terms of the relatively large volume of lamproite magma erupted in the $\sim 2.5 \mathrm{~km}$ diameter body where slow cooling allowed extended fractionation and the crystallisation of coarse grained to pegmatitic lamproites with abundant K-Ba-titanate minerals, apatite and wadeite, minerals normally found in the evolved groundmass of finer grained lamproites. The most MgO-rich of the Walgidee Hills lamproites ranges up to the most MgO-poor (22-24 wt \%) olivine lamproites found in the two largest pipes (Ellendale 4 and 9) of the Ellendale Field which also show (limited) evidence of petrographic and geochemical zoning (coarsening of the groundmass, minor geochemical variation) within their former lava lakes (Jaques et al. 1986; Stachel et al. 1994). The parent magma composition for the Ellendale lamproites is estimated to have been more primitive than that of Walgidee Hills containing $\sim 22 \mathrm{wt} \% \mathrm{MgO}$ and $\sim 1,000 \mathrm{ppm} \mathrm{Ni}$ (Foley 1993).

Diamond exploration has yielded mineral concentrates containing mantle fragments dominated by $\mathrm{Cr}$ Al spinel with rare Cr-pyrope (G9) garnet and traces of diamond indicating that the Walgidee Hills lamproite was likely derived from partial melting of mantle within the diamond stability field. Walgidee Hills, like the other Noonkanbah field lamproites, is slightly less geochemically enriched than the Ellendale lamproites, but trace element and $\mathrm{Sr}, \mathrm{Nd}$ and $\mathrm{Pb}$ isotope compositions indicate a similar origin involving small degrees of partial melting of a formerly depleted mantle source that has undergone long term (> 2 Ga) geochemical enrichment (Jaques et al. 1984, 1986; Nelson et al. 1986).

\section{References}

Foley SF (1993) An experimental study of olivine lamproite: First results from the diamond stability field: Geochim Cosmochim Acta 57:483-489

Jaques AL (2016) Major and trace element variations in oxide and titanate phases in the West Kimberley lamproites, Western Australia. Miner Petrol 110:159-197

Jaques AL, Lewis JD, Smith CB, Gregory GP, Feguson J, Chappell BW, McCulloch MT (1984) The diamond-bearing ultrapotassic (lamproitic) rocks of the West Kimberley region, Western Australia. In Kornbprobst J et al (eds) Kimberlites I: Kimberlites and related rocks, Elsevier, pp. 225-254

Jaques AL, Lewis JD, Smith CB (1986) The kimberlites and lamproites of Western Australia. Bull Geol Surv W Aust 132: $268 \mathrm{pp}$

Mitchell RH, Bergman SC (1991) Petrology of Lamproites. New York: Plenum, 447 pp.

Nelson DR, McCulloch MT, Sun SS (1986) The origins of ultrapotassic rocks as inferred from Sr, Nd and $\mathrm{Pb}$ isotopes. Geochim Cosmochim Acta 50:231-245

Stachel T, Brey G (1993) Spinels in the Ellendale olivine lamproites (Western Australia): significance for diamond distribution and emplacement history. Neues Jahrbuch Miner Abh 165: 155-167

Stachel T, Lorenz V, Smith CB, Jaques AL (1994) Volcanology and geochemistry of the Ellendale Lamproite Field, (Western Australia). In Meyer HOA, Leonardos OH (eds) Kimberlites, related rocks, and mantle xenoliths. CPRM-Special Publ 1/91:177-194

Wade A, Prider RT (1940) The leucite-bearing rocks of the West Kimberley area, Western Australia. Quart J Geol Soc Lond 96:39-98 